y 1

1
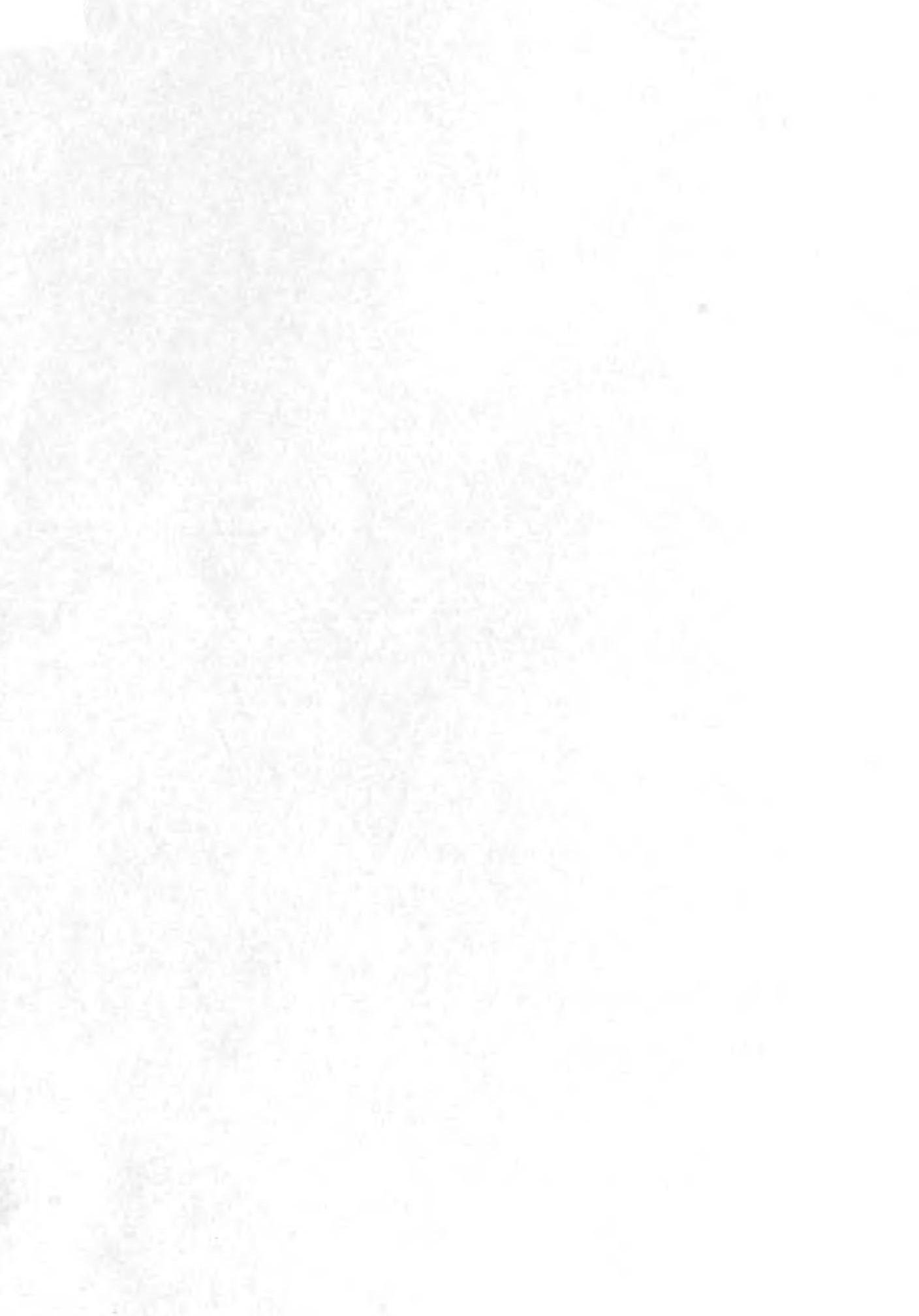


\section{The Growth of Field Corn as Affected by Iron and Aluminum Salts}

BY

CHARLES HOMER ARNDT

it

A THESIS

Presented to the Faculty of the Graduate School in Partial Fulifillment of the Requirements for The Degree of Doctor of Philosophy IN BOTANY 


\title{
The Growth of Field Corn as Affected by Iron and Aluminum Salts
}

\author{
BY CHARLES HOMER ARNDT
}

With Plate $I$ and Figures 1 and 6

\section{CONTENTS}

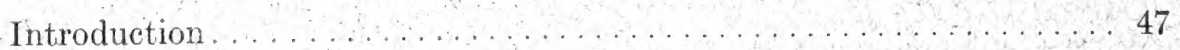

Historical Review . . . . . . . . . . . . . . . . . 47

The Present Investigation (Methods and Materials) . . . . . . . . 50

Germination .............................. 51

Solution Cultures. .......................... 52

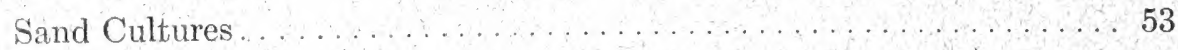

Experimental Data............................. 54

I. The Effect of the Composition of the Nutrient Solution upon the Availability of Iron in Ferric Phosphate......... 54

II. The Effect of Iron Salts in Solution "A" ........... 55

III. The Toxicity of Aluminum Salts and Acids in Solution " $A$ ". 57

IV. The Effect of Iron and Aluminum Salts upon Growth in Solu-

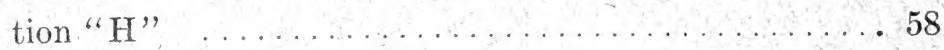

a. Solution Cultures ...................... 58

b. Sand Cultures ......................... 59

Discussion . . . . . . . . . . . . . . . . . . . 61

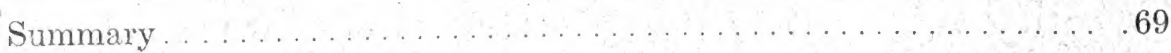

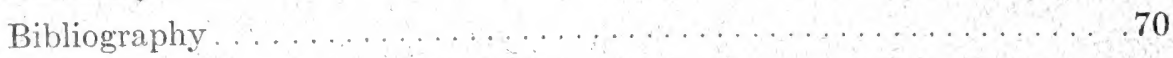


[Reprinted from the American Journal of Botany, 9: 47-71, February, 1922.]

\title{
THE GROWTH OF FIELD CORN AS AFFECTED BY IRON AND ALUMINUM SALTS
}

\author{
Charles Homer Arndt
}

(Received for publication May I 7, I921)

\section{INTRODUCTION}

The investigations of Hoffer and Carr ('20) on corn diseases have shown that a brown or brownish-purple discoloration of the lower portion of the nodal tissue is frequently associated with evidences of malnutrition and of root rot. This discolored area they have designated zone "B." Chemical analyses showed that a high iron or aluminum content was associated with such a discoloration. The injection of iron salts produced a similar brownish discoloration, increased the catalase and oxidase activities, and reduced the $\mathrm{H}$-ion concentration. Ferrous salts produced these effects more readily than did ferric salts. The injection of aluminum salts produced no discoloration, but had an effect similar to that of iron salts upon the physiological activities. Stalk- and root-rot organisms were usually associated with the accumulation of iron and aluminum in zone "B." Bordnár ('I 5) earlier reported a similar correlation between a high aluminum content of the sugar beet and its infection by bacterial organisms. His analyses showed that a high aluminum content preceded the infection, which indicates that an increased aluminum content is in some manner related to the decreased resistance to infection.

The present investigation was undertaken to determine whether toxic concentrations of iron and aluminum salts would produce a similar pathological condition in corn. With this object in view, a study was made of the effect of the composition of the nutrient solution upon the toxicity of sulphuric, nitric, and hydrochloric acids and of their corresponding salts with iron and aluminum.

\section{Historical Review}

Some investigators of the toxicity of aluminum salts believed that the toxicity is due largely to the acid liberated in the hydrolysis of the salts. Abbott, Conner, and Smalley ('I3) investigated the effect of aluminum nitrate and nitric acid on field corn. Their results indicated that nitric acid is as toxic as the same normality of aluminum nitrate. They

[The Journal for January $(9: \mathrm{I}-46)$ was issued February 2 I, I 922.] 
concluded that the toxicity is due to the hydrolysis of the aluminum salts with the accompanying liberation of nitric acid. Miyake ('I6) has compared the effect on rice seedlings of the same normality of aluminum chloride and hydrochloric acid. The toxicity of these two solutions was not greatly different. The $\mathrm{H}$-ion concentration produced by the acid was three times as great. This indicated that the toxicity must be due to something other than the $\mathrm{H}$-ion concentration. A similar conclusion was reached by Hartwell and Pember ('r 8 ) in their study of the effect of aluminum sulphate on barley and rye. The sulphuric acid produced a $\mathrm{H}$-ion concentration four times as great as the same normality of aluminum sulphate. The two substances were, however, alike toxic to barley. The acid depressed the growth of rye similarly to that of barley, but the salt had little effect on the rate of growth of rye. This indicated that plants may vary greatly in their tolerance of aluminum salts. Duggar ('I I) states that the various soluble inorganic salts of the same metal are of about equal toxicity. Rothert ('o6) has shown that this may not be strictly true for aluminum salts. Aluminum chloride was found to be much more toxic to corn than the sulphate. The toxicity of the salts was also dependent upon the method of application. They were most toxic when used alone in distilled water; less toxic in Knop's solution; and least toxic in soil cultures.

The toxicity of iron salts, particularly of the ferrous salts, when present in excess, is well known. Hartwell and Pember ('o8) determined the effect of ferrous sulphate upon the growth of rye and barley. Katayama ('o6) found that a concentration of ferrous sulphate of less than o.o I percent stimulated the growth of barley. Higher concentrations were toxic. Clover, according to Rupprecht (' 15 ), is seriously injured under certain conditions by ferrous salts in a concentration above 4 p.p.m. Iron hydrate when added to sand cultures is toxic to spinach. Analyses by Czadek ('o4) have shown that iron in this form is easily absorbed by spinach.

Iron salts, as aluminum salts, are readily hydrolyzed. Thus, they produce an increased acidity of the sand or solution cultures. Boiret and Paturel ('92) suggested that the toxicity of ferrous sulphate is due to the acid radicle. Ferric salts are even more easily hydrolyzed and precipitated in nutrient and soil solutions. The generally recognized greater toxicity of the ferrous salts, as compared to the ferric salts, indicates that at least in the case of the ferrous salts the toxicity is possibly due to something other than the acidity. This may be due in part, as has been suggested by Awatsu ('I4), to an abnormal stimulation of the physiological activities. The ferrous salts produce the greater effect on these activities. Maquenné and Demousy ('20) found that the addition of small amounts of copper sulphate to solutions containing a toxic concentration of ferrous sulphate reduced the toxicity. The addition of the copper to like solutions of ferric salts did not reduce the toxicity. They believe that the unlike effect is due to the catalytic action of the copper which hastens the oxidation of 
the ferrous salt to the less toxic ferric salt. The addition of calcium salts and phosphates to toxic solutions of both salts also lessened the injurious effect by aiding the formation of insoluble iron salts.

It has already been noted that most soluble iron and aluminum salts are readily hydrolyzed with an accompanying liberation of the acid radicle. Daikuhara ('I4), Abbott, Conner, and Smalley ('I3), Hartwell and Pember ('I8), and Mirasol ('20) state that all soils which indicate injury to plants by aluminum are acid. This acidity is usually reported as the lime requirement of the soil. Recent work by Joffe ('20) indicates that this lime requirement is closely related to the H-ion concentration. Duggar ('20) has shown that the $\mathrm{H}$-ion concentration may be a limiting factor in plant growth and that the effect of any particular concentration upon plant growth varies with the plant used. Good yields were secured with corn with $\mathrm{H}$-ion concentrations varying from a pH of 3.2 to one of $7 . \mathrm{I}$. The optimum H-ion concentration depended upon the nutrient solution and possibly to some extent upon the environmental conditions. Hoagland ('i 7 ) reported that a $\mathrm{H}$-ion concentration of $0.3 \times \mathrm{IO}^{-3}$ is toxic to barley seedlings. These facts emphasize the necessity of determining the depression caused by a $\mathrm{H}$-ion concentration in the nutrient solution, which lacks the toxic salt, equal to that which is produced by the hydrolysis of the iron and aluminum salts, if we wish to determine the toxicity of the salt itself. A comparison of the depression caused by the salt with that of an equal acidity produced by an acid whose anion is of little or no importance as a depressing factor, should give some indication of the toxicity of the salt itself.

Because of the importance of a suitable source of iron in nutrient solutions, it was necessary to ascertain the proper source of iron and the amount necessary to secure the optimum growth of corn. Mazé's ('I9) experiments with corn lead him to recommend ferric sulphate rather than ferrous sulphate as a source of iron. Shive ('I5), Tottingham ('I4), and others, in the study of the salt requirements of plants, have used ferric phosphate as a source of iron. Duggar ('20) has noted that corn grown in Shive's solution becomes chlorotic. The efficiency of ferric and ferrous phosphate has been compared by Corson and Bakke ('I7). They secured the best yield with the ferric salt. Shive and Jones ('2 I) have found lately that the use of ferrous sulphate as a source of iron in wheat cultures gives superior growth to that secured in cultures in which ferric phosphate is used. Preliminary experiments showed that ferric phosphate is not a suitable source of iron for corn in solutions of Type I as recommended by the Committee of the National Research Council on the Salt Requirements of Representative Agricultural Plants. Consequently, experiments were made to determine the form of iron necessary to assure a sufficient supply to prevent a lack of it from limiting the growth of the plants. 


\section{The Present Investigation}

Solution cultures were used in the main part of this experimental work. These results were checked with sand cultures to determine to what extent the solution cultures might indicate the toxicity of these salts in the soil. In all cases the weight of the plants grown in the unmodified solution was taken as the control. The effect of the acid or salt is indicated as the percentage of the weight of the plants grown in solutions containing them, as compared with the control culture. The weight in the control was taken as Ioo percent. For the tops the green weight was used as a criterion of the relative growth, as this probably gives the best indication of the condition of the plants. Comparisons of the green and dry weights gave similar relative weights. As a criterion of the root development, the dry weight was used. The roots were placed in weighed test tubes and dried at I $00^{\circ} \mathrm{C}$. for several days.

The $\mathrm{H}$-ion concentration for the solutions was determined by means of the Lubs and Clark (Clark, '20) series of indicators, using the buffer mixtures recommended by them. These were carefully prepared from recrystallized salts. Standards were kept in Pyrex test tubes of Io cc. capacity, the solutions to be tested were placed in similar test tubes, and the same concentration of the indicator was added to them. The $\mathrm{H}$-ion concentration of the sand cultures at the time of the renewal of the solutions was determined by adding distilled water to bring the sand to 60 percent of its water-holding capacity; $50 \mathrm{cc}$. of the solution was drawn off by suction through a hose previously rinsed with distilled water; the new solution was then added, and the remaining $450 \mathrm{cc}$. was withdrawn. The $\mathrm{pH}$ value is reported for the $50 \mathrm{cc}$. and for the total $500 \mathrm{cc}$. drawn off. All solutions were clear. Consequently, turbidity did not interfere with the determinations. The $\mathrm{pH}$ values given to show the effect of the growth of the plants upon the reaction of the solution were determined just previously to the time of harvesting the plants. This was usually at the end of a warm, sunny period favorable for growth, as these conditions seemed to have an important effect on the results.

The seed corn used in these experiments was Reid's Yellow Dent, a variety of yellow dent (or, according to Sturtevant ('94), Zea mays var. indentata), which was furnished by Dr. G. N. Hoffer. It gave practically Ioo percent germination. Very few grains showed any infection by parasitic organisms. The salts used were Baker "analyzed" chemicals. The ferric phosphate was prepared as recommended by the Committee of the National Research Council on Salt Requirements of Representative Agricultural Plants. All stock solutions of the salts and acids were made up as $N /$ io solutions. These were made up fresh at least twice a week, except the ferrous sulphate which was made up immediately before it was used. The distilled water was prepared with a Barnstead still and was stored in glass containers. 
In the solution cultures, pint Mason jars and colorless cylindrical museum jars of $900 \mathrm{cc}$. capacity were used. These were treated with cleaning fluid for several hours before each experiment. The jars were completely covered with opaque black paper. A loose shell of stiff light-brown cardboard was placed over this. Flower pots were used for the sand cultures. These were thoroughly impregnated with heated paraffin and then well coated on the inside with a thin layer of the same. The sand was procured from the Whitall Tatum Company. It is the brand known as "Juniata." It was prepared as recommended by the Committee on the Salt Requirements of Representative Agricultural Plants. It had a waterholding capacity of 32 percent. It was kept at 60 percent of its waterholding capacity throughout the experiment by the method recommended by the above-named Committee.

The relative transpiration of the plants grown in the various solutions was determined from the amount of water added daily to replace the water which had been lost. The relative transpiration here reported is based on the loss for a certain period immediately preceding the time when the plants were harvested. During this period the evaporating power of the atmosphere was determined by standardized spherical white and black atmometer cups. To keep the conditions of light and temperature as nearly uniform as possible for all cultures, as no rotating tables were available, the plants were shifted daily in a systematic manner so that each plant occupied the same position for about the same period during the experiment.

Each solution culture contained four plants. Five plants were grown in each pot in the sand cultures. In most cases the cultures were run in duplicate series, so that the relative growth is based on the total weight of eight or ten plants. The weights reported in the tables are based on the mean weight of one plant.

\section{Germination}

The seed used was carefully selected for uniformity of size and shape. The seed was soaked for 15 minutes in tap water, drained, and allowed to stand at room temperature for two hours. It was next treated for I 5 minutes with a 5 percent calcium hypochlorite solution $(5 \mathrm{~g}$. per IOO cc.). This was removed by washing the seed several times with boiled tap water. It was finally soaked for $\mathrm{I} 2$ hours in a shallow covered dish in just sufficient boiled water to cover the seed. After soaking, the seeds were distributed on filter paper in germinating dishes and covered with a layer of filter paper. The dish was placed in the greenhouse, covered with glass, and flooded once a day with water. When the radicles were one centimeter long, the seeds were removed to a paraffined germination net made of coarse netting. This was stretched over an inverted twenty-liter bell jar, and filled with a solution of one tenth the concentration of the solution $\mathrm{R}_{2} \mathrm{~S}_{3}$ 
of the Type I solutions recommended by the Committee on the Salt Requirements of Representative Agricultural Plants. In addition, 2 g. of calcium carbonate was added to each jar. Tap water was used instead of distilled water. Consequently, the exact composition of this solution is not known, but as it gave excellent results, it was probably as good as any solution which can be used until we have some definite information concerning the effect of various solutions on the germination of corn. The seedlings were left on the net until the shoots were about $6 \mathrm{~cm}$. long. This required from 6 to 9 days. Ten times as many seeds were soaked as were finally used. This number was reduced by one half at the time the seedlings were transferred to the net. At the time the seedlings were transferred to the solutions a second selection of the best seedlings was made. For the solution cultures these were wrapped loosely with cotton above the seed and placed in one-half-inch holes in paraffined corks. When they were to be grown in sand, the seed was placed just below the surface.

\section{Solution Cultures}

(a) Solution "H." The solution which Hartwell and Pember ('I8) found satisfactory for studying the effect of aluminum sulphate on barley and rye, was found to be well adapted for the growth of corn. It was modified slightly to secure a better growth of corn. Its composition, as used, is as follows:

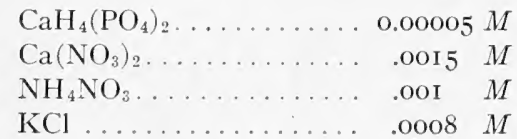

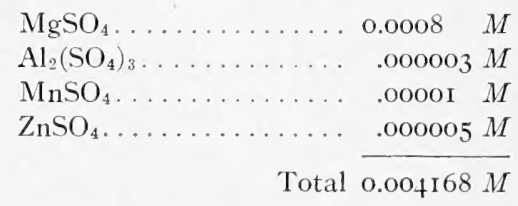

Total $0.004168 M$

To this was added $7 \mathrm{mg}$. of $\mathrm{FePO}_{4}$ per liter. For convenience, this solution will be referred to as solution "H." Preliminary experiments indicated that Hartwell's solution gave the best results when aluminum, zinc, and manganese were added. The work of Mazé ('15) on the salt requirements of corn suggested this modification. The phosphate concentration of the solution used is about twice that recommended by Hartwell and Pember. There was no sign of precipitation when aluminum salts were added and the solution was allowed to stand a week. Again, all solutions were changed every other day, or at one half the interval used by Hartwell and Pember. The ferrous-sulphate solutions were changed every day to prevent, as far as convenient, the change from the ferrous to the ferric condition. It was impossible to prevent precipitation when the ferric salts were used. Consequently, the results may not truly represent the relative toxicity of the ferrous and the ferric salts.

(b) Solution "A." A number of preliminary experiments demonstrated that with solutions of Type I as recommended by the Committee on the 
Salt Requirements of Representative Agricultural Plants, a solution of one half the molecular concentration of $\mathrm{R}_{2} \mathrm{~S}_{3}$ was well within the range necessary for the optimum growth of corn. A solution was used whose partial volume-molecular proportions were as follows: $\mathrm{KH}_{2} \mathrm{PO}_{4}, 0.0024 \mathrm{M}$; $\mathrm{Ca}$ $\left(\mathrm{NO}_{3}\right)_{2}, 0.0036 M ; \mathrm{MgSO}_{4}, 0.0035 M$. This solution probably had an osmotic pressure close to 0.5 atmosphere.

In this solution it was impossible to prevent precipitation when the various salts were added. Consequently, the results of the experiments in which this solution was used are not strictly comparable with those in which solution "H" was used. They are comparable when considered in relation to the effect of the composition of the nutrient solution upon the tolerance of acidity by corn. Because of this precipitation, a renewal of the solutions at small intervals would have had little effect on the amount of the salt in the solution. To economize time, the ferrous sulphate solutions of o.ooI $N$ and higher were changed twice a week; the others were changed once a week.

\section{Sand Cultures}

Solution "H" was used in all sand cultures. The method of McCall ('I6) as modified by Johnson ('20) was used for changing the solution. The cultures containing ferrous sulphate were renewed every day; the others, every third day. The sand did not contain sufficient iron for the optimum growth of corn. Ferric phosphate was added to the solution as in the solution cultures. The ferric phosphate was added to the ferroussulphate cultures every third day, as most of the phosphate probably was held in the sand and was not withdrawn when the solutions were renewed.

After $2000 \mathrm{~g}$. of sand was placed in each pot, it was thoroughly washed a second time by drawing 3 liters of distilled water through it. The sand used for the acid cultures was treated for 48 hours with strong sulphuric acid and then thoroughly washed until the water withdrawn was neutral. These sand cultures were not covered with a wax seal. This was thought desirable in order to simulate soil conditions as far as possible. A wax seal would have reduced the aëration and induced conditions in the soil which would undoubtedly have increased the toxicity of the ferrous salts. In order to secure some idea of the relative amount of water lost through evaporation and transpiration, a pot without plants was placed in the series and treated as the others. The amount lost through transpiration was calculated by deducting the loss from this pot from the total loss of the other cultures. The error introduced by this method of determining the transpiration should be small, as the loss through evaporation was relatively small in comparison to the total water loss.

The writer wishes to express to Dr. J. W. Harshberger his sincere appreciation of the interest and assistance which made possible the experiments, and to acknowledge his indebtedness to Dr. G. N. Hoffer of the Office of 
Cereal Investigations of the United States Department of Agriculture for the suggestion of the problem and for much valuable information. Dr. Alice M. Russell has added greatly to the interest of the investigation by her mycological study of the discolored nodes. To Dr. R. H. True and to other members of the Botanical Department of the University of Pennsylvania, the writer is greatly indebted for generous help and criticisms.

TABle I. The Effect of the Composition of the Nutrient Solution upon the Availability of Iron in Ferric Phosphate

\begin{tabular}{|c|c|c|c|c|c|}
\hline \multirow{2}{*}{ Solution } & \multirow{2}{*}{$\begin{array}{c}\mathrm{Mg} . \mathrm{FePO}_{4} \\
\text { per } \\
\text { Liter }\end{array}$} & \multicolumn{2}{|c|}{ Total Weight } & \multicolumn{2}{|c|}{ Relative Weight } \\
\hline & & Tops & Roots & Tops & Roots \\
\hline 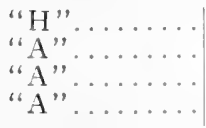 & $\begin{array}{l}7 \\
3 \cdot 5 \\
\text { I } 4 \\
35\end{array}$ & $\begin{array}{l}82.6 \mathrm{gm} . \\
34.4 \text { “" } \\
43.9 \\
59.8+\text { " }\end{array}$ & $\begin{array}{l}3.8+\mathrm{gm} \\
2.24 \\
2.3 \\
3.68\end{array}$ & $\begin{array}{r}\text { IOO\% } \\
42 \% \\
53 \% \\
72 \%\end{array}$ & $\begin{array}{l}100 \% \\
58 \% \\
59 \% \\
97 \%\end{array}$ \\
\hline
\end{tabular}

\section{Experimental Data}

\section{The Effect of the Composition of the Nutrient Solution Upon the Avail- ability of Iron in Ferric Phosphate}

Four cultures were set up in duplicate as shown in table I. The plants were grown in the 8oo-cc. jars during the period from February 7 to March 5, I92 I. The " $\mathrm{H}$ " solutions were changed twice a week; the others every
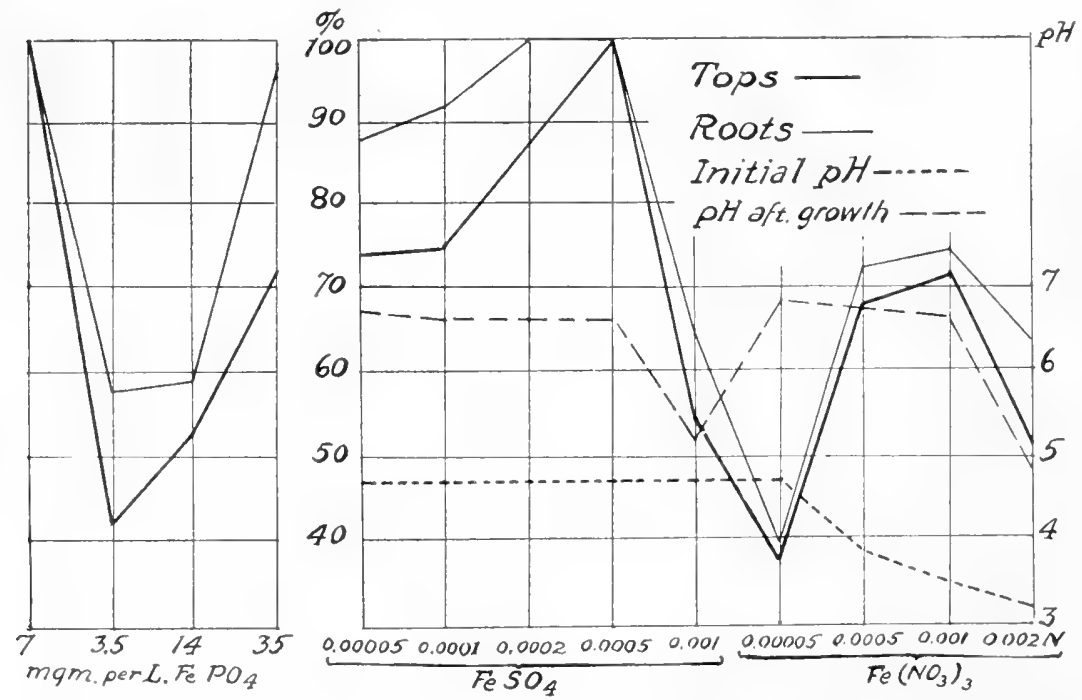

FIG, I (left). Relative growth of roots and tops with $\mathrm{FePO}_{4}$ in solution "A" (3.5, I 4,35$)$ and " $\mathrm{H} "(7)$.

FIG. 2 (right), Relative growth in solution "A" with FeSO, and $\mathrm{Fe}\left(\mathrm{NO}_{3}\right)_{3}$. Also $\mathrm{H}$-ion concentration before and after growth. 
week. All the plants in solution "A" were unquestionably chlorotic, which fact indicated that they did not secure sufficient iron. The plants grown in solution " $\mathrm{H}$ " were of a normal color. Other experiments showed that an increase of iron in this solution did not increase the yield. An increase in the amount of ferric phosphate in solution " $\mathrm{A}$ " did increase the yield. The color of the plants, however, indicated that the iron was not available in sufficient quantities. Plate IV and also figure I show clearly the difference of growth in the various concentrations.

\section{The Effect of Iron Salts in Solution "A"}

Two preliminary experiments, in which ferrous sulphate was used as a source of iron, were made in the fall of 1920 . This was a poor period for growth because of the great amount of cloudy weather. The results are of interest in comparison with those of the experiment performed under more favorable conditions during March, I92I. In this experiment, the plants were grown for 25 days in $800-\mathrm{cc}$. jars. The first two experiments will be referred to in table 2 as series $\mathrm{I}$ and 2 respectively; the latter as series 3. The relative transpiration is reported for the last week of growth for series 3. During this period the average daily loss from the white and the black atmometer was I I.4 cc. and I 3.6 cc. respectively.

TABLE 2. The Efject of Iron Salts upon the Relative Yields of Tops and Roots and upon Transpiration in Solution "H"-Also the Initial pH and the pH After Growth

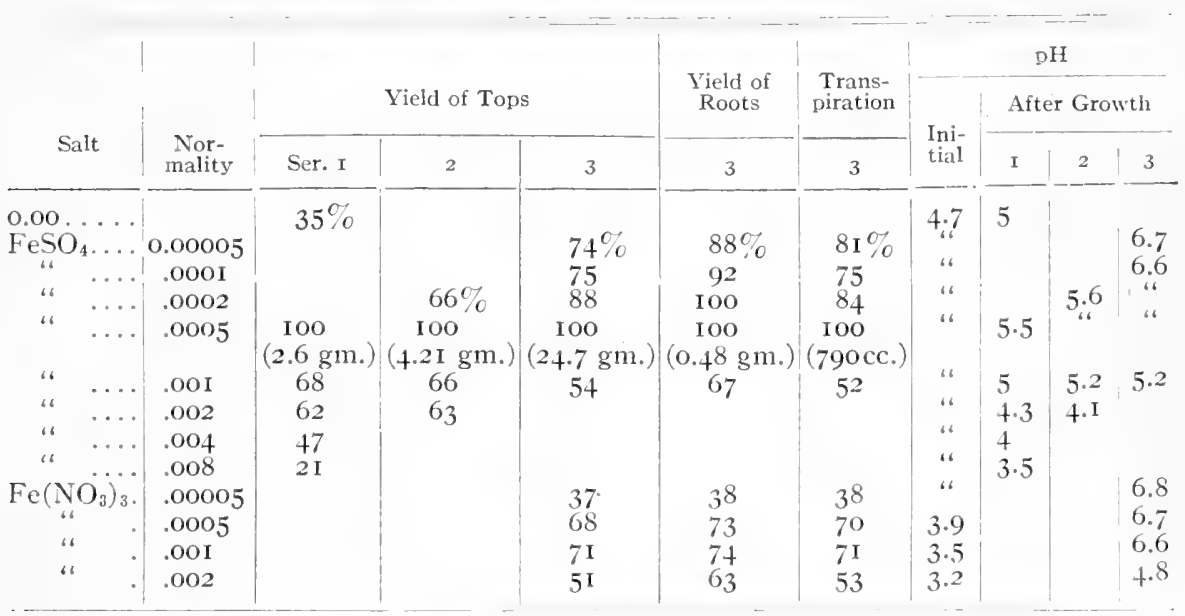

All plants grown in the solutions containing ferric nitrate were chlorotic. This fact, and the low yields associated with it, indicated that ferric nitrate was much inferior to ferrous sulphate as a source of iron in solution "A." In all cases, the best yield was secured with $0.0005 N$ ferrous sulphate. The above-noted results for series 3 are shown graphically in figure 2. A comparison of figures I and 2 shows that the lack of iron does not usually 
depress root development as much as it does that of the tops. It is interesting to note the poor root development in $0.0005 N$ ferric nitrate. There is little difference in the relative growth with either salt in 0.00I $N$ and $0.002 N$. It is singular that ferric nitrate should begin to depress growth before it supplies sufficient iron for normal growth.

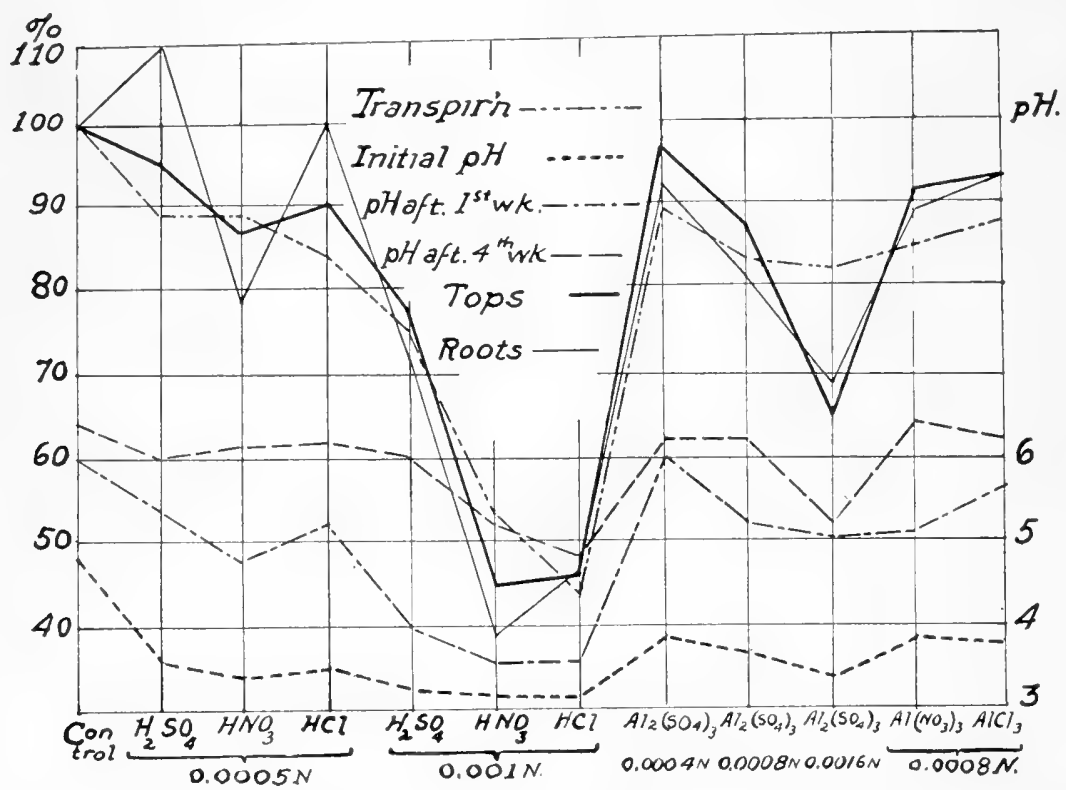

FIG. 3. Relative growth and the H-ion concentration upon the addition of acids and aluminum salts to solution "A.". The $\mathrm{H}$-ion concentration is given for the initial solution and at the end of the first and last weeks of growth.

TABLE 3. The Efiect of Acids and Aluminum Salts in Solution "A"

\begin{tabular}{|c|c|c|c|c|c|c|c|}
\hline \multirow{2}{*}{$\begin{array}{c}\text { Sol. "A" } \\
\text { plus }\end{array}$} & \multirow{2}{*}{$\begin{array}{l}\text { Nor- } \\
\text { mality }\end{array}$} & \multicolumn{2}{|c|}{ Rel. Weight } & \multirow{2}{*}{$\begin{array}{l}\text { Rel. } \\
\text { Transpir- } \\
\text { ation }\end{array}$} & \multirow{2}{*}{$\begin{array}{l}\text { Ini- } \\
\text { tial }\end{array}$} & \multicolumn{2}{|c|}{$\begin{array}{l}\mathrm{pH} \\
\text { After Growth }\end{array}$} \\
\hline & & Tons & Roots & & & Ist wk. & 4th wk. \\
\hline $0.00 \ldots \ldots \ldots$ & & $\begin{array}{c}100 \% \\
(10.1 \mathrm{gm} .)\end{array}$ & $\begin{array}{c}100 \% \\
(0.24 \mathrm{gm} .)\end{array}$ & $\begin{array}{c}100 \% \\
(560 \mathrm{cc} .)\end{array}$ & 4.8 & 6 & 6.4 \\
\hline $\mathrm{H}_{2} \mathrm{SO}_{4} \ldots \ldots$ & 0.0005 & 95 & 105 & 89 & 3.6 & $5 \cdot+$ & 6 \\
\hline & $.00 I$ & 77 & 73 & 75 & $3 \cdot 3$ & + & 6 \\
\hline $\mathrm{HNO}_{3} \ldots \ldots$ & .0005 & 87 & 77 & 89 & $3 \cdot 4$ & 4.8 & 6.2 \\
\hline$" \quad \ldots \ldots$ & $.0 O I$ & 45 & 38 & 53 & 3.2 & 3.6 & 5.2 \\
\hline $\mathrm{HCl} \ldots \ldots$ & .0005 & 90 & IOO & 84 & 3.5 & 5.2 & 6.2 \\
\hline$" \ldots \ldots \ldots$ & .001 & 46 & $3^{8}$ & 44 & 3.2 & 3.6 & 4.8 \\
\hline $\mathrm{Al}_{2}\left(\mathrm{SO}_{4}\right)_{3} \ldots$ & .0004 & 98 & 93 & 89 & 3.9 & 6 & 6.2 \\
\hline$\because \quad \ldots$ & .0008 & 87 & $8 \mathrm{I}$ & 83 & 3.7 & 5.2 & 6.2 \\
\hline " & .0016 & 65 & 69 & 82 & $3 \cdot 4$ & 5 & 5.2 \\
\hline $\mathrm{Al}\left(\mathrm{NO}_{3}\right)_{3} \ldots$ & .0008 & $9 \mathrm{I}$ & 89 & 85 & 3.9 & 5.2 & 6.4 \\
\hline $\mathrm{AlCl}_{3} \ldots \ldots$ & .0008 & 93 & 98 & 88 & 3.8 & 5.6 & 6.2 \\
\hline
\end{tabular}




\section{The Effect of Aluminum Salts and Acids Upon Growth in Solution "A"}

The object of this series of experiments was to determine the relative toxicity of hydrochloric, nitric, and sulphuric acids and their corresponding aluminum salts. The solution was modified by the addition of the acids and the salts as shown in table 3 . As previously stated, the aluminum salts were precipitated in this solution, and the concentration added does not represent the amount remaining in solution. The results, consequently, do not represent the real relation between the toxicity of the acid and that of the salts. The plants were grown for zo days during the month of April in a shaded greenhouse. Pint Mason jars containing $400 \mathrm{cc}$. of the culture solutions were used. The results are shown graphically in figure 3. The weather was very favorable during the first portion of the period. There was practically no sunshine during the last week. This fact, undoubtedly, accounts for the small change in the $\mathrm{pH}$ value for the last week of growth.

TABLE 4. The Effect of Acids and Iron and Aluminum Salts upon Growth in Solution "H"

\begin{tabular}{|c|c|c|c|c|c|c|c|c|}
\hline \multirow{3}{*}{$\begin{array}{l}\text { Sol. " "H" } \\
\text { plus }\end{array}$} & \multirow{3}{*}{$\begin{array}{l}\text { Nor- } \\
\text { mality }\end{array}$} & & & \multirow{3}{*}{$\begin{array}{l}\text { Yield of } \\
\text { Roots } \\
2\end{array}$} & \multirow{3}{*}{$\begin{array}{l}\text { Transpir- } \\
\text { ation } \\
2\end{array}$} & \multicolumn{3}{|c|}{$\mathrm{pH}$} \\
\hline & & \multicolumn{2}{|c|}{ Vield of Tops } & & & \multirow{2}{*}{$\begin{array}{l}\text { Ini- } \\
\text { tial }\end{array}$} & \multicolumn{2}{|c|}{$\begin{array}{l}\text { After } \\
\text { Growth }\end{array}$} \\
\hline & & Ser. I & 2 & & & & I & 2 \\
\hline Control........ & & $\begin{array}{c}100 \% \\
(\mathrm{I} 7.5 \mathrm{gm} .)\end{array}$ & $\begin{array}{c}100 \% \\
(20.2 \mathrm{gm})\end{array}$ & $\begin{array}{c}\mathrm{IO0} \% \\
(0.58 \mathrm{gm} .)\end{array}$ & $\begin{array}{c}100 \% \\
(7+5 \mathrm{cc} .)\end{array}$ & 4.9 & 4.9 & 6.2 \\
\hline $\mathrm{H}_{2} \mathrm{SO}_{4} \ldots \ldots \ldots$ & $\begin{array}{r}0.0002 \\
.0004\end{array}$ & $\begin{array}{l}97 \\
7 \mathrm{I}\end{array}$ & 78 & $7 \mathrm{I}$ & & 3.7 & 4.6 & \\
\hline$" \quad \ldots \ldots \ldots$ & $\begin{array}{l}.0004 \\
.0006\end{array}$ & $\begin{array}{l}7 \mathrm{I} \\
88\end{array}$ & $\begin{array}{l}78 \\
67\end{array}$ & $\begin{array}{l}71 \\
65\end{array}$ & $7+$ & 3.5 & $4 \cdot 3$ & 6.2 \\
\hline $\mathrm{HNO}_{3} \ldots \ldots \ldots$ & $\begin{array}{l}.0006 \\
.0002\end{array}$ & 90 & 0, & 65 & 69 & $\begin{array}{l}3.2 \\
3.7\end{array}$ & $\begin{array}{l}3.5 \\
4.6\end{array}$ & 6 \\
\hline$" \quad \ldots \ldots \ldots$ & .0004 & 82 & 76 & 69 & 68 & 3.4 & $4 \cdot 3$ & 6 \\
\hline$"{ }^{6} \quad \ldots \ldots \ldots$ & .0006 & 68 & 62 & 55 & $5^{I}$ & 3.2 & $4 \cdot 5$ & 5.6 \\
\hline $\mathrm{HCl} \ldots \ldots \ldots$ & .0002 & 97 & & & & 3.7 & $4 \cdot 3$ & \\
\hline$"$ " $\quad \ldots \ldots \ldots \ldots$ & .0004 & 82 & 88 & $7 \mathrm{I}$ & $8+$ & $3 \cdot 5$ & 3.7 & 6.2 \\
\hline$" \ldots \ldots \ldots \ldots$ & .0006 & 69 & 63 & 53 & 49 & 3.2 & $3 \cdot 4$ & $5 \cdot 4$ \\
\hline $\mathrm{FeSO}_{4} \ldots \ldots$ & .0002 & 72 & $7 \mathrm{I}$ & 66 & 60 & 4.6 & 4.8 & $4 \cdot 4$ \\
\hline$\Leftrightarrow \ldots \ldots$ & .0004 & 62 & 52 & $5+$ & 50 & 4.6 & 4.6 & 3.8 \\
\hline$\ldots \ldots \ldots$ & .0006 & $4 I$ & & & • & 4.2 & $4 \cdot 3$ & \\
\hline $\mathrm{Fe}_{2}\left(\mathrm{SO}_{4}\right)_{3} \ldots \ldots$ & .0002 & IOO & & & & + & 5 & \\
\hline$\ldots \ldots$ & .0004 & 72 & 67 & 66 & 52 & 3.7 & $4 \cdot 3$ & $4 \cdot 7$ \\
\hline " $\quad \ldots \ldots$ & .0006 & 75 & 73 & $6 \mathrm{I}$ & 67 & $3 \cdot 5$ & $3 \cdot 5$ & 4.7 \\
\hline $\mathrm{Fe}\left(\mathrm{NO}_{3}\right)_{3} \ldots \ldots$ & .0002 & 97 & & & & + & $4 \cdot 3$ & \\
\hline " $\quad \ldots \ldots$ & .0004 & 69 & 62 & 65 & $5+$ & 3.7 & $4 \cdot 3$ & 4.6 \\
\hline${ }^{\prime \prime} \quad \ldots \cdots \cdot$ & .0006 & $5^{2}$ & $6+$ & 57 & 59 & 3.5 & $4 \cdot 3$ & 4.7 \\
\hline $\mathrm{FeCl}_{6} \ldots \ldots$ & .0002 & 95 & & & & 4 & 4.2 & \\
\hline$" \quad \ldots \ldots \ldots$ & .000 .4 & 86 & 63 & $6 I$ & 56 & 3.6 & $4 \cdot 3$ & $4 \cdot 7$ \\
\hline$" 6 \ldots \ldots$ & .0006 & 67 & $5 \mathrm{I}$ & $5 I$ & $5+$ & $3 \cdot 5$ & $3 \cdot 5$ & 3.3 \\
\hline $\mathrm{Al}_{2}\left(\mathrm{SO}_{4}\right)_{3} \ldots \ldots$ & $.000 I$ & $9 I$ & 88 & 88 & $8+$ & 4.2 & 4.8 & 5.8 \\
\hline$" \quad \ldots \ldots$ & .0002 & 84 & $7+$ & 73 & 66 & $4 \cdot I$ & 4.7 & 4.8 \\
\hline$\ldots \ldots$ & .0004 & 73 & 62 & 59 & 52 & 3.9 & 4.2 & 4.2 \\
\hline$" \quad \ldots \ldots$ & .0006 & 64 & 57 & 67 & 5.3 & 3.8 & 3.9 & 4 \\
\hline $\mathrm{Al}\left(\mathrm{NO}_{3}\right)_{3} \ldots \ldots$ & .0002 & 63 & 66 & 67 & 63 & 4.2 & 4.7 & 4.6 \\
\hline$" \quad \ldots \ldots$ & .0004 & 53 & 57 & 50 & $5^{2}$ & 4.2 & 4.3 & 3.7 \\
\hline${ }_{10}^{16} \quad \cdots \cdots$ & .0006 & 50 & 53 & 48 & 45 & 4 & 4.1 & 4.2 \\
\hline $\mathrm{AlCl}_{3} \ldots \ldots$. & .0002 & & 73 & 74 & 66 & 4.2 & & 4 \\
\hline$\ldots \ldots$ & .0004 & & $6+$ & 62 & 52 & $4 \cdot 1$ & & 3.9 \\
\hline$" \quad \ldots \ldots \ldots$ & .0006 & & 64 & 60 & 49 & 3.9 & & $3 \cdot 5$ \\
\hline
\end{tabular}


The $\mathrm{pH}$ value at the end of the first week is also given. The water loss by transpiration is given for the entire growth period. The average daily loss from the white and black atmometers was $5.83 \mathrm{cc}$. and $6.49 \mathrm{cc}$., respectively.

\section{The Effect of Iron and Aluminum Salts Upon Growth in Solution "H"}

(a) Solution Cultures. As solution " $\mathrm{H}$ " has been previously described, only a brief account of the experiment and the environmental conditions will be given here. The pint jars and $450 \mathrm{cc}$. of the culture solutions were used in all cases. Series I was run for 37 days during January and February. Conditions for growth at the beginning of the experiment were not very

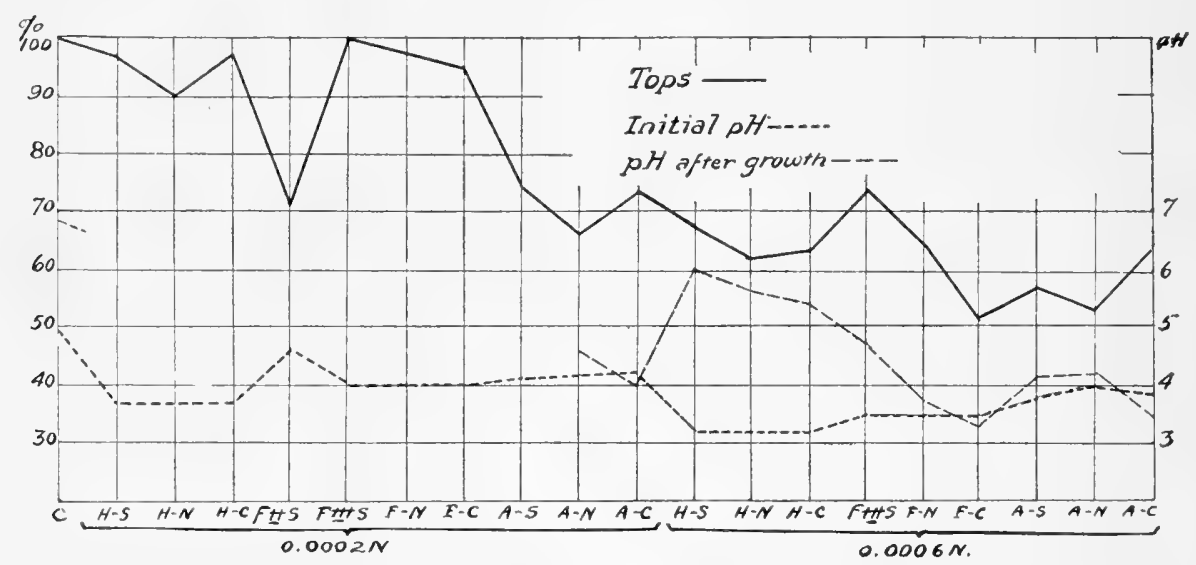

Frg. 4. Relative weight of tops and $\mathrm{H}$-ion concentration before and after growth in solution " $\mathrm{H}$ " as they were affected by the addition of acids and salts in $0.0002 N$ and 0.0006 $N$ concentration. In this and the following figures, the following notation is used: $C$, control; $H, F$, and $A$ denote the cations $\mathrm{H}, \mathrm{Fe}$, and $\mathrm{Al}$. The anions are indicated thus: $S=\mathrm{SO}_{4} ; N=\mathrm{NO}_{3} ; C=\mathrm{Cl}$. Ferrous and ferric sulphate are distinguished by plus signs; $F++S=$ ferrous sulphate, $F^{+++S}=$ ferric sulphate.

favorable. Conditions were very favorable for growth during the 37 -day period in which series 2 was grown. The plants grew rapidly and seemed to be in excellent condition until several days before the end of the experiment, when the leaves of some of the plants were unable to open because of the formation of a mucilage-like substance. This was most noticeable in the solutions containing aluminum. This pathological condition was associated with a number of bright sunny days during which it was impossible to keep the greenhouse temperature below $32^{\circ} \mathrm{C}$. It never exceeded $35^{\circ} \mathrm{C}$. The relative transpiration is given for series 2 and is based upon the transpiration for the last week of growth. During this period the average daily loss from the white and the black atmometers was II.4 cc. and I $3.6 \mathrm{cc}$, respectively. 
(b) Sand Cultures. The plants in the sand cultures were grown for 40 days in April and May. The modifications of solution " $H$ " and the

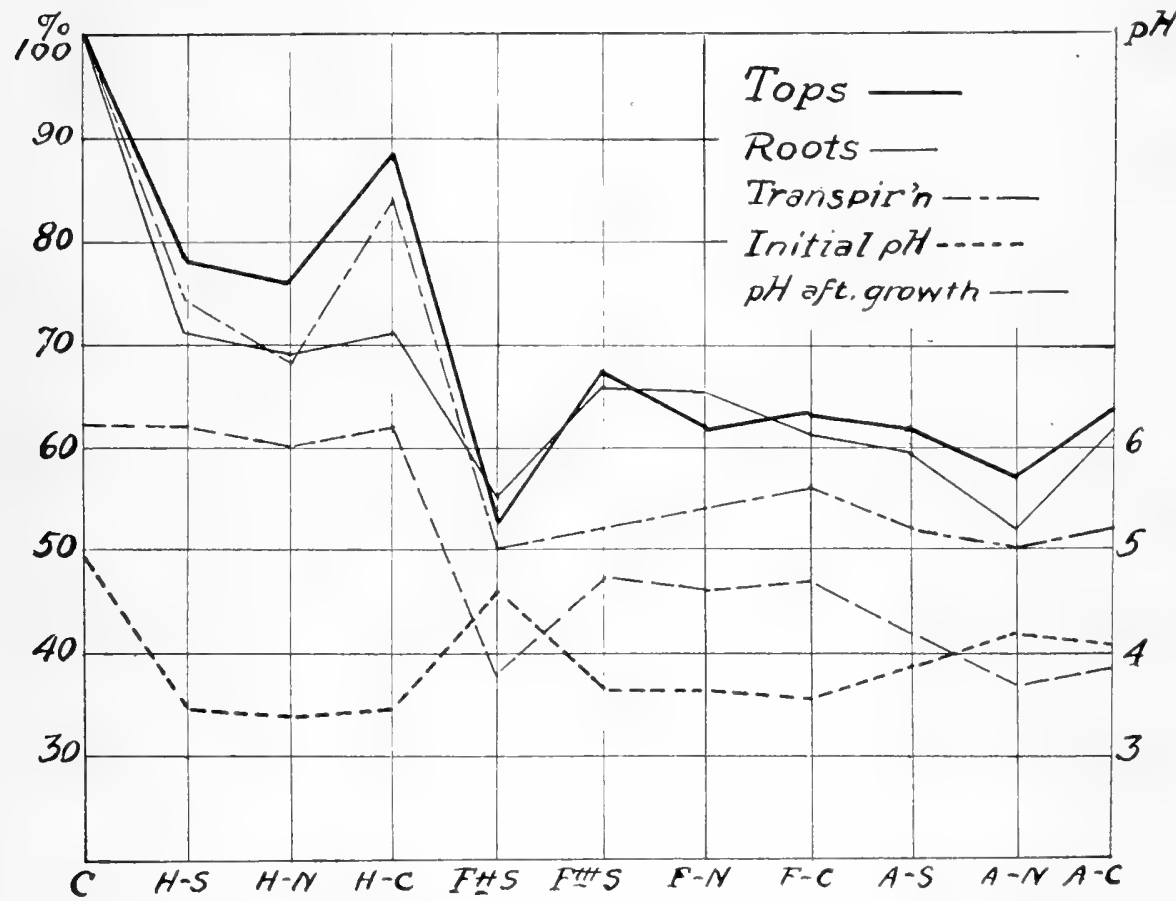

FIG. 5. Relative growth of tops and roots, transpiration, and the $\mathrm{H}$-ion concentration before and after growth in solution " $\mathrm{H}$ " upon the addition of $0.000+\mathrm{N}$ acid and salts. For notation see figure 4 .

results are given in table 5. The transpiration is reported for the last I6 days of growth. The total average loss by evaporation from the pots without plants, which was deducted from the total loss of the others to determine the amount lost by transpiration, was $405 \mathrm{cc}$. During the period of growth the average daily loss from the white and black atmometers was $7.83 \mathrm{cc}$. and $8.5 \mathrm{cc}$. respectively. The small difference between these values is due to the fact that the plants were grown in a well shaded greenhouse and to the large proportion of cloudy weather during the first part of the experiment. On sunny days the temperature ranged from $30^{\circ} \mathrm{C}$. to $35^{\circ} \mathrm{C}$. This was probably too high for the optimum growth of corn. The $\mathrm{pH}$ values are given for the first $50 \mathrm{cc}$. and for the total $500 \mathrm{cc}$. drawn off at the end of the second week, and also at the time of the last renewal for which the $\mathrm{pH}$ value of the last $50 \mathrm{cc}$. is also given. The change in the $\mathrm{pH}$ values of the initial solutions by plant growth was much greater in the sand cultures than in the solution cultures, as is well shown in figure 6. The depression of growth of the tops is also on an average less, and particularly so in case 
TABLE 5. The Efject of Acids and Iron and Aluminum Salts upon Growth in Sand Cultures

\begin{tabular}{|c|c|c|c|c|c|c|c|c|c|c|}
\hline \multirow{3}{*}{$\begin{array}{c}\text { Sol: "H" } \\
\text { Plus }\end{array}$} & \multirow{3}{*}{$\begin{array}{l}\text { Nor- } \\
\text { mality }\end{array}$} & \multirow{3}{*}{$\begin{array}{l}\text { Weight } \\
\text { of Tops }\end{array}$} & \multirow{3}{*}{$\begin{array}{l}\text { Root } \\
\text { Score } \\
\text { - }\end{array}$} & \multirow{3}{*}{$\begin{array}{c}\text { Transpi- } \\
\text { ration }\end{array}$} & \multicolumn{6}{|c|}{$\mathrm{pH}$} \\
\hline & & & & & \multicolumn{3}{|c|}{ End $2 d$ wk- } & \multicolumn{3}{|c|}{ End last wk. } \\
\hline & & & & & $\begin{array}{l}\text { Ini- } \\
\text { tial }\end{array}$ & $\begin{array}{l}50 \\
\mathrm{cc} .\end{array}$ & $\begin{array}{l}500 \\
\mathrm{cc} .\end{array}$ & $\left|\begin{array}{cc}\text { rst } \\
50 & \mathrm{cc}\end{array}\right|$ & $\begin{array}{l}500 \\
\text { cc. }\end{array}$ & $\begin{array}{c}\text { Last } \\
50 \mathrm{cc} \text {. }\end{array}$ \\
\hline Control. & & $\begin{array}{c}\mathrm{IOO}^{6} \mathrm{o} \\
(\mathrm{I} 2.8 \mathrm{gm} .)\end{array}$ & $2 \mathrm{I}$ & $\begin{array}{c}100 \% \\
(\mathrm{I} 4 \mathrm{IOCC})\end{array}$ & 4.9 & 6.2 & 6.2 & 6.4 & 6 & 6 \\
\hline $\mathrm{H}_{2} \mathrm{SO}_{4} \ldots \ldots$ & $0.00 \mathrm{I}$ & 9 I & I6 & 100 & 3 & $5 \cdot 4$ & 3.8 & 5.6 & 3.8 & 3.6 \\
\hline " $\ldots \ldots \ldots$ & .002 & 59 & 8 & 52 & 2.8 & $3 \cdot 4$ & 3 & 3.4 & 3 & 3 \\
\hline $\mathrm{HNO}_{3} \ldots \ldots \ldots$ & $.00 \mathrm{I}$ & IOI & 14 & 98 & 3 & 5 & 3.8 & 6 & 4 & 3.6 \\
\hline $\mathrm{HCl} \ldots . . . .$. & .001 & 89 & I I & 86 & 3 & $5 \cdot 4$ & 3.8 & 5.6 & 3.6 & 3.6 \\
\hline $\mathrm{FeSO}_{4} \ldots \ldots \ldots$ & .0002 & 102 & 23 & 99 & 4.6 & 5.8 & 5.6 & 4.8 & 4.6 & 4.6 \\
\hline$" \quad \ldots \ldots \ldots$ & .0004 & 88 & 2 & 79 & 4.6 & 5.6 & 5.6 & $4 \cdot 4$ & 4.2 & 4.2 \\
\hline " & .0006 & 49 & o & 60 & 4.2 & 3.8 & 3.6 & 3.4 & 3.4 & 3.6 \\
\hline $\mathrm{Fe}_{2}\left(\mathrm{SO}_{4}\right)_{3} \ldots \ldots$ & .0004 & 79 & 10 & 75 & 3.7 & 5.8 & 5.8 & 5.8 & 5.2 & 5 \\
\hline $\mathrm{Fe}\left(\mathrm{NO}_{3}\right)_{3} \ldots \ldots$ & .0004 & 80 & 8 & 69 & 3.7 & 5.6 & 5.8 & 5.2 & 5 & 4.8 \\
\hline $\mathrm{FeCl}_{3} \ldots \ldots \ldots$ & .0004 & 66 & 6 & $6 \mathrm{I}$ & 3.7 & 6 & 5.8 & 5.6 & 5 & 4.8 \\
\hline $\mathrm{Al}_{2}\left(\mathrm{SO}_{4}\right)_{3} \ldots \ldots$ & .0002 & 69 & 4 & 70 & 4.1 & 6 & 6 & 6.2 & 6 & 5.8 \\
\hline$\ldots \ldots \ldots$ & .0004 & 66 & 3 & 69 & 3.9 & 5.8 & 5.8 & 5.8 & 5.2 & 4.8 \\
\hline " $\quad 1 \ldots \ldots$ & .0006 & 57 & & 58 & 3.9 & & & 4.1 & 4 & \\
\hline $\mathrm{Al}\left(\mathrm{NO}_{3}\right)_{3} \ldots \ldots$ & .0002 & 73 & 6 & 74 & 4.2 & 6 & 6 & 6.2 & 6 & 5.8 \\
\hline$" \quad \ldots \ldots \ldots$ & .0004 & 54 & 5 & $6+$ & 4.2 & 6 & 6 & $5 \cdot 4$ & 4.8 & 4.8 \\
\hline " $1 \ldots$ & .0006 & 54 & & 58 & 4 & & & 4 & 5 & \\
\hline $\mathrm{AlCl}_{3} \ldots \ldots \ldots$ & .0002 & 80 & 9 & 76 & 4.2 & 5.8 & 6 & 6 & 5.8 & $5 \cdot 4$ \\
\hline$\ldots \ldots \ldots$ & .0004 & 63 & I & 67 & 4.1 & 6.2 & 6.2 & $5 \cdot 4$ & 4.8 & 4.8 \\
\hline$" 1 \ldots \ldots \ldots \ldots$ & .0006 & 56 & & $4^{8}$ & 4 & & & 4 & 4 & \\
\hline
\end{tabular}

of the peculiar behavior of ferrous sulphate at $0.0002 N$ and $0.0004 N$. This difference is probably accounted for by the better aëration of the sand cultures. It is still more unusual to have the lower concentration give a slightly higher yield than the control, and $0.0004 N$ a higher yield than the same concentration of the ferric salts. This is probably to be explained by the fact that the ferrous solutions were renewed every day; the others every 3 days. The addition of sand to the culture solution changed greatly the toxicity of the acids. The average depression in the sand cultures for 0.00I $N$ acid was 6 percent, and in the solution cultures for $0.0004 N$ it was 2 I percent.

The aluminum salts produced approximately the same depression in both types of cultures. The corresponding average depressions in the sand and solution cultures for $0.0002 N$ are 26 percent and 28 percent, and for $0.0004 N, 39$ percent and 40 percent, respectively. The extensive researches of Shive ('20) have indicated that this similarity in effect in sand and solution cultures is to be expected when the solutions are changed at frequent intervals, and that such factors as chemical action and precipitation must not be considered.

The inhibiting effect upon root development of the acids and of the iron and aluminum salts was much less in the sand than in the solution cultures. A $0.0006 N$ concentration of ferrous sulphate in the sand cultures in-

${ }_{1}^{1}$ These results are taken from a series run previous to the time the other cultures were grown. 
hibited their development relatively less than $0.0002 N$ in the solution cultures, o.00I $\mathrm{N} \mathrm{H}_{2} \mathrm{SO}_{4}$ less than $0.0006 \mathrm{~N}$; and $0.0004 \mathrm{~N}$ of the aluminum salts much less than $0.0002 N$. In the solution cultures the dry weight was used as a criterion of relative root growth. The results, for reasons to be

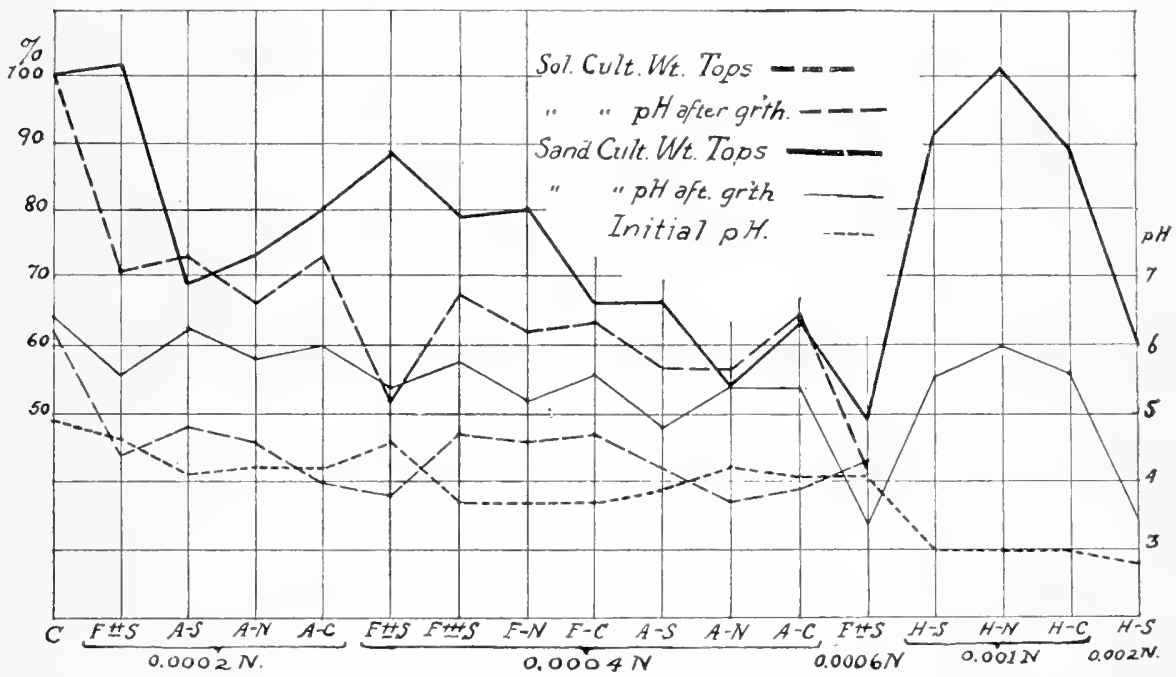

FIG. 6. Relative growth in sand and solution cultures and the effect of plant growth upon the $\mathrm{H}$-ion concentration. For notation see figure 4 .

discussed later, were not satisfactory. In this experiment the roots were washed free of sand and then compared by the method devised by Free ('15). A comparison can readily be made by reference to the numbers reported. The highest number indicates the best root development.

\section{Discussion}

It is plainly evident from the experiments described in the preceding pages that the effect of any particular salt upon plant growth depends largely upon the composition of the solution in which the plants are grown. One of the best examples is the difference in the availability of the iron in ferric phosphate in solutions "A" and "H." Something in solution "A" prevents the plant from absorbing the iron. This is not due to any inherent property of the ferric phosphate. At the time series 2 of experiment 4 was run, plants were grown in a modified solution " $\mathrm{H}$." The calcium phosphate was replaced by an equivalent molecular weight of ferric phosphate. The growth of the tops in these cultures relative to the control was 95 percent; of the roots, 68 percent, and the transpiration was 96 percent. The plants were as well developed as those of the controls. The lower nodes of these plants did not show any discolored nodes, such as were found when the plants were grown in the solution with this concentration 
of the other iron salts. This behavior of ferric phosphate was very interesting when it formed as a precipitate when ferric nitrate was added directly to solution "A." A 0.00 I $N$ concentration did not produce plants of a normal green color. A $0.002 N$ concentration was decidedly toxic. It is singular that growth should be depressed by the addition of an iron salt, before sufficient iron is available for the growth of the plant. When the efficiency of ferric nitrate as a source of iron is compared with that of ferrous sulphate, the result is striking. At $0.0005 \mathrm{~N}$, the yield in the latter is 68 percent of that in the former; while at $0.00 \mathrm{I} N$, the ferrous salt becomes very toxic and the ferric salt gives the better yield. This greater physiological activity of the ferrous salt may be correlated with its greater influence on catalytic activities. Other factors, however, may be concerned. The ferrous salt is less readily precipitated than the ferric. There may also be a difference in the solubility of the two phosphates which may be influenced by the concentration of phosphorus and calcium in the solution. Any attempt at an explanation of this difference can be only speculative until more data are available.

The concentration of ferrous sulphate necessary to give the maximum yield with corn in solution "A" is probably close to $0.0005 N$. This is approximately $\mathrm{I} 4 \mathrm{mg}$. per liter. The iron requirements of corn are evidently very different from those of wheat and probably also from those of rice as determined by Shive and Jones ('2I) and Gile and Carrero ('20). The findings of Corson and Bakke ('i 7 ) apparently are not applicable to corn. It is somewhat difficult to interpret Mazé's recommendation of a ferric rather than a ferrous salt. He used a concentration of $50 \mathrm{mg}$. of ferrous sulphate per liter, an amount which would have been extremely toxic in solution "H." Mazé ('I3) noted that everything depends on the relative proportion of all elements. This is well illustrated by the behavior of ferrous sulphate in solutions " $\mathrm{H}$ " and "A." A concentration of it in solution " $\mathrm{H}$," two fifths of that required for optimum growth in solution "A," reduced the yield 25 percent to 30 percent. A doubling of this concentration in solution " $\mathrm{H}$ " reduced the yield almost 50 percent. The three ferric salts are about alike toxic, and their effect upon growth in solution "H," when compared to ferrous sulphate, is practically of the same order as the relative efficiency of ferric nitrate and ferrous sulphate in promoting growth in solution "A." At a $0.0002 N$ concentration they are practically without effect upon the yield; and at $0.0004 N$, they gave about a I 5 percent better yield than the ferrous salt.

The toxicity of aluminum salts at the higher concentrations does not seem to be a function of the concentration. The average depressions are: 0.000I $N$ Io percent, $0.0002 N_{2} 8$ percent, $0.0004 N_{4}$ percent, $0.0006 N_{42}$ percent in the solution cultures, and $0.0002 N 26$ percent, $0.0004 N 39$ percent in the sand cultures. There is an increase in toxicity of aluminum salts, as measured by yield of tops, with increasing concentration; but it is 
not at all proportional to the increase in concentration. The effect on the development of the roots is more nearly related to the concentration. This difference in root development is much greater than is actually indicated by the small differences in the relative root yields. The development of the small secondary roots is inhibited at the higher concentrations; but coinciding with the stunting of the secondary roots there is a thickening of the main roots and an increased formation of prop roots, which increases the weight of the root system. Because of this fact, the dry weight is a poor criterion of the root development and of the number of feeding roots. In the solution cultures, the roots were barely able to penetrate a solution of $0.0006 \mathrm{~N}$, no secondary roots formed, and the root tips were frequently swollen and recurved. Nevertheless, the roots were able to absorb sufficient material to produce a stunted growth. The poor development of the roots in the higher concentration probably accounts to some extent for the tendency of chlorosis to be associated with aluminum injury. It is likely that the capacity of aluminum salts to antagonize the action of iron salts, as has been noted by Stoklasa (' $18 b$ ), may be the most important factor.

The effect of aluminum salts on root development described above is similar to that noted by Rothert ('o6) in his study of the effect of aluminum chloride and sulphate upon the growth of Zea mays. He states that the shoots suffer the least and the secondary roots the most. A I percent solution was necessary to depress growth in Knop's solution, which is many times the concentration necessary to depress growth in solution "H." Hartwell and Pember ('I8) secured a 44 percent depression of the growth of barley with $0.0008 \mathrm{~N}$ aluminum sulphate in solution "H." It is very likely that this concentration would not produce a much greater depression with corn.

Some interesting suggestions as to the possible cause for this peculiar action of aluminum salts may be found in the studies of Stoklasa ('r $8 a, b$ ), Berthelot and André ('95), and Meurer ('08). The latter has shown that the amount of aluminum absorbed by slices of beet or carrot roots from a solution of one of its salts is independent of the concentration of the salt in the solution. Tissue killed by chloroform absorbs the aluminum as readily as living tissue. He concludes that aluminum forms some chemical compound with the pectic bodies of the middle lamella. The relatively lesser toxicity of aluminum salts at increased concentrations has led Stoklasa ('1 $8 b$ ) to conclude that aluminum combines with the cell wall to form colloidal salts. This action renders the cell less permeable. The researches of Szücs ('12) demonstrated that it also acts on the protoplasm and causes it to set. The singular thickening of the main roots of the plants grown in the solution cultures is probably due to some unique action of the aluminum upon the tissues of the root. Berthelot and André grew plants in pot cultures to which aluminum salts were added. In all the plants grown in their cultures, aluminum oxide formed a much larger 
percentage of the ash of the roots than of the tops. They concluded that aluminum after absorption is fixed and thus rendered immobile. Stoklasa ('I $8 a$ ) has shown that the amount of aluminum in the roots of mesophytic plants is determined largely by the amount of soil moisture. An increase in the soil moisture increased the percentage of aluminum in the roots, but not in the tops in which the percentage was always low. These facts probably explain the lessened depression of root growth by the aluminum salts in the sand cultures. Rothert's analyses of the corn plants which he grew in the cultures containing aluminum showed a large percentage of aluminum in the ash of the roots and only a trace in the tops. Hoffer and Carr ('20) have shown that most of the aluminum which is carried to the stem accumulates in the nodal area. Microchemical tests made with plants grown in the present experiment confirm this finding.

In the present investigation no evidence has been found to confirm Rothert's statement that aluminum chloride is more toxic than aluminum sulphate. There is some indication of a slightly greater toxicity of the aluminum nitrate.

The H-ion concentrations of solutions " $\mathrm{A}$ " and " $\mathrm{H}$ " are slightly below those which Duggar ('20) has given as the optimum for corn. The slight depression of growth caused by $0.0002 \mathrm{~N}$ concentration of $\mathrm{H}_{2} \mathrm{SO}_{4}$ in solution " $\mathrm{H}$," by $0.0005 N$ in solution "A," and by $0.001 \mathrm{I}$ in the sand cultures, indicates that an initial acidity above $\mathrm{pH} 3.7$ in solution " $\mathrm{H}$," above $\mathrm{pH}$ 3.6 in solution " $\mathrm{A}$," and above $\mathrm{pH} 3.6$ in the sand cultures had little effect upon the growth of field corn. When the initial concentration of the acid in solution " $\mathrm{H}$ " is increased to $0.0004 N(\mathrm{pH} 3.5)$, there is a distinct depression which is greater than that caused by $0.001 N\left(\mathrm{pH}_{3}\right)$ in the sand cultures. A $0.0006 \mathrm{~N}$ concentration of nitric, hydrochloric, or sulphuric acid is decidedly toxic in the solution cultures. The three acids produced a similar depression of the relative weight of tops and roots. The roots were much better developed in the sulphuric acid solutions, when compared with the effects of the other acids, than is indicated by the relative weights. A similar difference was noted in the solutions containing the three ferric salts. This feature is clearly shown in Plate IV, figure C. The difference in development is in harmony with the favorable effect of sulphates on the root development of certain plants which has been noted by Tottingham and Hart ('I5). In solution "A," as shown in figure 3 , the sulphuric acid gave a better yield of the tops than did the other acids. This is most marked with a concentration of $0.001 N$. The relative yields reported in this paper, indicating the effects of the various concentrations of the acids in solution " $\mathrm{H}$ " on corn, are very similar to those given for wheat, barley, and oats by Hartwell and Pember ('o7).

It will be noted from the tables and figures that the solutions in general tended to become less acid with the growth of the plants. A similar tendzncy has been noted by Duggar ('20), Salter and McIlvaine ('20), and 
Hoagland ('19). The acid solutions were more readily shifted toward neutrality than the solutions containing the iron and aluminum salts. There seems to be a tendency for the sulphuric acid solutions to be shifted most readily, particularly in solution "A." The effect of the acid radicle of the aluminum salts in determining the shifting of the reaction is shown by a comparison of the initial $\mathrm{H}$-ion concentration and the concentration after growth. This is well shown by the various graphs. The sulphate solutions, with the exception of those containing ferrous sulphate, are unique in that in all cases the $\mathrm{H}$-ion concentration was shifted toward neutrality. The reverse was true of the solution cultures containing ferrous sulphate even at the low concentration of $0.0002 N$., All solutions containing nitrates become less acid except $0.0004 N$ aluminum nitrate. The chlorides showed a strong tendency to increase the initial $\mathrm{H}$-ion concentration. This tendency was shown by all concentrations of aluminum chloride in solution " $\mathrm{H}$," and also by $0.0006 \mathrm{~N}$ ferric chloride. In the sand cultures the $0.0006 N$ ferrous sulphate solution was the only one which showed after plant growth a $\mathrm{H}$-ion concentration higher than the initial concentration of the solution.

The results of Salter and McIlvaine show that a $\mathrm{H}$-ion concentration less than that necessary to depress growth in solution " $H$ " may produce a distinct depression in other nutrient solutions. They found that a reaction of $\mathrm{pH}$ 4.I I was much less favorable to corn than a reaction of $\mathrm{pH} 5.16$, in their strongly buffered solutions. The great changes in the reaction of solutions "A" and " $\mathrm{H}$ " produced by the growth of corn indicate that possibly the initial concentration of the solution is not as important a factor in plant growth as is the buffer action of the solution which determines the ease with which the plant can shift the reaction. It is very likely that the toxicity of the acids in solutions " $\mathrm{A}$ " and " $\mathrm{H}$ " could have been increased either by using larger amounts of the solutions, or by renewing them more frequently. A survey of the tables will show that the shifting of the reaction is roughly proportional to the size of the plant. Thus, the $\mathrm{pH}$ values given in table 3 and figure 3 show that the change in the reaction is greater at the end of the fourth than at the end of the first week; and in table 4 it appears that the series (ser. 2) which gave the greatest total growth also produced the greatest change in reaction.

In solutions containing ferrous sulphate, growth shifted the $\mathrm{H}$-ion concentration in the opposite direction. The change was almost negligible at the beginning; but as the plants became larger, the $\mathrm{H}$-ion concentration was increased. A solution with a similar concentration of the salt was kept in the greenhouse in a flask for three days without a change equal to $\mathrm{pH}$ 0.2. It seems fairly evident that the plant in some manner accelerates the hydrolysis and the precipitation of the salt and is the main agency which produces the change in acidity. The ferric salts are immediately precipitated, giving a high initial acidity to the solution. The ferrous sait 
is less readily precipitated, but when conditions are such as to favor its precipitation a similar acidity is produced.

A comparison of the relative yields in solution " $\mathrm{H}$," as shown in figures 4,5 , and 6 , of the acids and the aluminum salts, points to the cation of the salt rather than the $\mathrm{H}$-ion concentration produced by the hydrolysis of the salts as the toxic factor. The reverse is true in solution "A" (fig. 3). The results in solution " $\mathrm{H}$ " indicate that corn is affected by soluble aluminum salts similarly to rice (Miyake, 'I6) and barley (Hartwell and Pember, 'I 8; Conner, '2I). A closer relation seems to exist between t' e ability of the plant to shift the reaction toward neutrality and the relative toxicity of the acid and the salt, than exists between the initial $\mathrm{H}$-ion concentration and the toxicity of the salt. This inability of the plant to change the reaction may be a secondary feature, for, as has been previously pointed out, this change is related to the amount of plant growth and it may be merely a measure of the toxicity of the solution rather than the cause of the toxicity. These results are not in harmony with the conclusions of Abbott, Conner, and Smalley ('13). These authors based their conclusions largely upon the root development of seven-day-old seedlings. Plate IV, figure $\mathrm{B}$, which shows the relative development in $0.0004 \mathrm{~N}$ acid and in the same normality of the corresponding aluminum salts, indicates that there is a distinct difference between the toxicity of the acid and that of the salts as measured by root development when a longer period of growth is used. These results agree with those of Miyake. He based his conclusions on the relative elongation of the shoots and states that there is little difference in the toxicity of the same strengths of the acid and of the salt. His results on root elongation show that the root growth in the acid was twice as great as in the corresponding salt solution. The relative toxicity of the acid and the salt in solution " $\mathrm{H}$ " depends somewhat on the concentration used. Except in the case of sulphuric acid, there is little difference in the toxicity of the acid and of the corresponding salt in a $0.0006 N$ concentration; while at $0.0002 N$, the acid has practically no effect upon growth and the salt produces a considerable reduction of growth. A comparison of the relative effects of the acid and of the salt, as shown by the results given for the sand cultures in table 5 and in figure 6 , is even more favorable to the acid. These results are also more dependable when considered in relation to the $\mathrm{H}$-ion concentration, as the buffer action of the sand kept the concentration more constant; although it is possible that the concentration reported does not represent the acidity of the solution in contact with the roots. In these cultures a $0.002 N$ concentration of sulphuric acid in the culture was necessary to produce the same depression as $0.0006 \mathrm{~N}$ aluminum sulphate. The difference in $\mathrm{H}$-ion concentration is still greater. In the acid cultures it was approximately four times as great, as marked by the difference between $\mathrm{pH} 3.4$ and $\mathrm{pH}$ 4.I. This indicates that the theory advanced by Abbott, Conner, and Smalley, which 
states that the toxicity of aluminum nitrate toward field corn is largely due to the acidity produced by the hydrolysis of the salt, is no longer tenable. It has been previously noted that all soils which show aluminum injury are acid. A comparison of the $\mathrm{pH}$ values reported at the end of the second and at the last renewal (5th week) in the sand cultures shows an increase in acidity of the cultures by the continued addition of aluminum salts, which fact supports the belief that the hydrolysis of aluminum salts may be an important factor in the production of soil acidity through the reactions noted by Noyes ('19).

Hartwell and Pember ('08, p. 293), after their investigation of the effect of the same normality of sulphuric acid and ferrous sulphate on barley and rye, conclude that the injury caused by the salt is largely due to the liberation of the acid radicle in hydrolysis. A comparison of the relative growth which they report for $0.0004 N$ ferrous sulphate and the growths given here in table 4 shows that this is not the case with corn in solution "H." A $0.0002 N$ ferrous-sulphate concentration depressed the growth almost 30 percent, but it did not produce an acidity greater than $\mathrm{pH}$ 4.4. Since the H-ion concentration of the solution used by Hartwell and Pember is not stated, it is somewhat difficult to compare their results with those of the present experiment. A still greater difference will be noted in the sand cultures where a $0.0006 \mathrm{~N}$ concentration of ferrous sulphate produced a Io percent greater depression than $0.002 \mathrm{~N}$ sulphuric acid. The $\mathrm{H}$-ion concentration of both cultures is the same. The score given in table 5 to indicate the relative root development is very favorable to the acid solution. The cultures in solution "A" show most clearly that the toxicity of ferrous sulphate is in no way related to an increase in acidity. The o.ooI $N$ ferrous sulphate culture never showed a $\mathrm{H}$-ion concentration below that of the initial solution, but it did produce a 35 percent to 45 percent reduction of growth.

The toxic effects of the ferric salts in the solution cultures were more nearly related to the $\mathrm{H}$-ion concentration than was the case with either the ferrous or the aluminum salts. This is because they are immediately precipitated. Thus, they produce a high initial $\mathrm{H}$-ion concentration. In the sand cultures the 0.00 I $N$ acids gave a far better yield than a $0.0004 N$ concentration of the iron salts. A comparison of the acids and the ferric salts in these cultures is probably not permissible because the rapid precipitation of these salts probably caused a much higher concentration of iron in the sand cultures than is indicated by the original solution. If such was the case, the increased relative injury as compared with the solution cultures must have been due to the precipitated, but probably slightly soluble, ferric phosphate and hydroxide.

The results given in tables 2 and 3 and plotted in figures 2 and 3 seem to indicate that in solution "A" the toxicity of iron and aluminum salts is largely due to the acidity produced when the salts are precipitated. The 
than the same normality of the other two acids. This difference was even more favorable to the sulphuric acid when the root development was compared. The nitrates and chlorides of aluminum and iron also depressed root growth more than the sulphates.

With solutions "A" and " $\mathrm{H}$," an initial $\mathrm{H}$-ion concentration less than $\mathrm{pH} 3.7$ had little effect upon the rate of growth. In most cases the plant tended to shift the reaction toward neutrality. On the contrary, when ferrous sulphate and certain concentrations of the chlorides were added to the cultures, plant growth increased the initial $\mathrm{H}$-ion concentration of the solution. The reaction was most readily shifted toward neutrality when the acidity was due largely to sulphuric acid and least readily when due to hydrochloric acid. The amount of shifting of the reaction was approximately the inverse of the toxicity of the salt or of the acid; i.e., the change in reaction was proportional to the size and the activity of the plant.

The toxicity of ferrous sulphate showed no relation to the initial $\mathrm{H}$-ion concentration. A $0.0002 N$ concentration depressed growth 27 percent in solution "H." The ferrous sulphate was approximately twice as toxic as the same normality of the ferric salts. The latter were more readily precipitated, and their depressing effect was closely related to the $\mathrm{H}$-ion concentration produced by their hydrolysis or precipitation.

In solution " A" the aluminum salts were readily precipitated, and their toxicity was evidently due largely to the $\mathrm{H}$-ion concentration thus produced. In solution " $\mathrm{H}$ " the toxicity was due to the aluminum ion. A $0.0002 . N$ concentration produced about the same depression as the same normality of ferrous sulphate. The development of the secondary roots was inhibited by a $0.0006 N$ concentration. The nitrate seemed to be somewhat more toxic than the other aluminum salts and showed a greater tendency to produce chlorosis.

Sand cultures greatly increased the concentration of acids necessary to produce the same effect when compared to their effect in the solution cultures. The same concentration of the salts produced about the same depression of the relative weights of the tops in both types of cultures. The use of the sand medium lowered the toxicity of the salts to the roots proportionally more than it increased the yield of the tops.

The composition of the nutrient solution had a greater influence in determining the toxicity of the salts than the medium in which the plants were grown.

Iron salts when present in injurious concentrations produced a reddishbrown discoloration of the lower portion of the nodal area. Aluminum salts collected in the same position but produceed no discoloration.

BOTANICAL LABORATORIES,

University of Pennsylyania

\section{BIBLIOGRAPHY}

Abbott, J. B., Conner, S. B., and Smalley, H. R. ('I3). Ind. (Purdue Univ.) Agr. Exp. Sta. Bull. I70. I9I3.

Awatsu, H. ('I 4 ). Arch. Int. Pharm. Therap. 23:325-352. I9I4. 

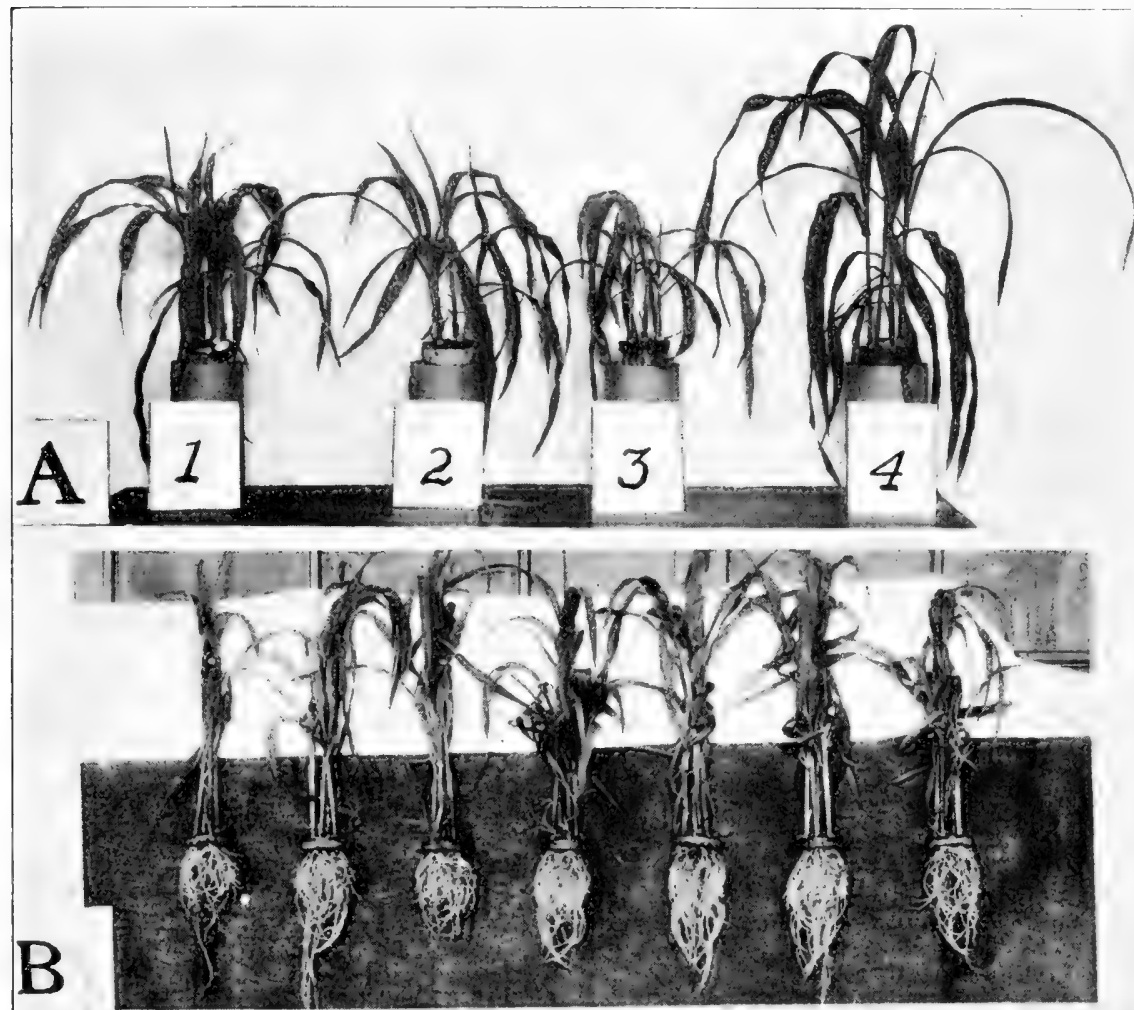

$\mathrm{Al}\left(\mathrm{NO}_{3}\right)_{3}-\mathrm{HNO}_{3}-\mathrm{Al}_{2}\left(\mathrm{SO}_{4}\right)_{3}-\mathrm{H}_{2} \mathrm{SO}_{4}-\mathrm{CrOn}_{\mathrm{tro}}-\mathrm{HCl} \mathrm{AlCl}_{3}$

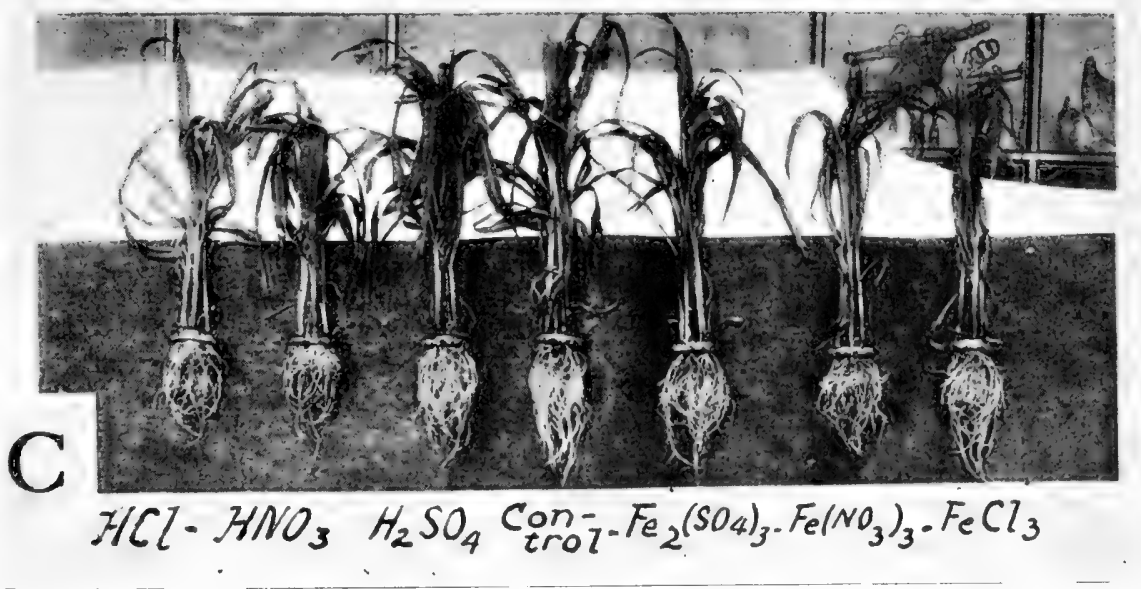




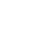


Berthelot and André, G. ('95). Compt. Rend. Acad. Sci. Paris r 20: 288-290. I 895.

Boiret, H., and Paturel, G. ('92). Ann. Agron. I8: 4I7-440. 1892.

Bordnár, J. ('I 5). Biochem. Zeitschr. 69: 245-256. I915.

Clark, W. M. ('20). The determination of hydrogen ions. Baltimore, r920.

Conner, S. D. ('2I). Jour. Amer. Soc. Agron. I3: I1 3-I24. I92I.

Corson, G. E., and Bakke, A. L. ('17). Proc. Iowa Acad. Sci. 24: 477-482. 1917.

Czadek, O. von ('o4). Zeitschr. Landw. Versch. Oesterr. 7: 65-67.' I904. Abstr. in Exp. Sta. Record I5: 964. I904.

Daikuhara, G. ('r4). Bull. Imp. Cent. Agr. Exp. Sta. Japan 2: I-40. I9I4.

Duggar, B. M. ('I I). Plant physiology. New York, I9II.

('20). Ann. Mo. Bot. Gard. 7: 1-49. I920.

Free, E. E. ('I5). Plant World I8: 249-256. I91 5 .

Gile, P. L., and Carrero, J. O. ('20). Jour. Agr. Res. 20: 32-62. 1920.

Hartwell, B. L., and Pember, F. R. ('o7). Ann. Rept. R. I. Agr. Exp. Sta. 20: 358-38o. 1907.

('o8). Ann. Rept. R. I. Agr. Exp. Sta. 2I: 286-294. 1908.

- ('I8). Soil Sci. 6:259-277. I9I8.

Hoagland, D. R. ('i 7 ). Soil Sci. 3: $547-560$. I9I 7 . ('19). Jour. Agr. Res, 18: 73-117. I9I9.

Hoffer, G. N., and Carr, R. H. ('20). Phytopath. 10: 56, 57. I920.

Joffe, J. S. ('20). Soil Sci. 9: 26I-266. I920.

Johnson, E. S. ('20). Soil Sci. 10: 389-409. 1920.

Katayama, T. ('o6). Bull. Coll. Agr. Tokyo 7: 9I-93. 1906.

McCall, A. G. ('I6). Soil Sci. 2: 207-25.3. 1916.

Maquenné, L., and Demousy, E. ('20). Compt. Rend. Acad. Sci. Paris II7: 21 8-222. I920.

Mazé, P. ('I3). Ann. Inst. Pasteur 27:65I-68I. I9I3.

- ('I5). Compt. Rend. Acad. Sci. Paris I60: 21 I-2I4, I9I5.

('I9). Ann. Inst. Pasteur 33: I39-I73. I919.

Meurer, R. ('o8). Jahrb. Wiss. Bot. 46: 502-567. 1908.

Mirasol, J. ('20). Soil Sci. ro: 153-218. 1920.

Miyake, J. ('I6). Jour. Biol. Chem. 25:23-26. I9I6.

Moore, B. ('I4). Proc. Roy. Soc. London, B, 87: 556-570. I9I4.

Noyes, H. A. ('I9). Jour. Ind, Eng. Chem. II: I040-1042. I9I9.

Rothert, W. ('o6). Bot, Zeit. 64: 43-52. 1906.

Rupprecht, R. W. ('I5). Mass. Agr. Exp. Sta. Buil. I6I. I9I5.

Salter, R. M., and McIlvaine, T. C. ('20). Jour. Agr. Res. 19: 73-95. 1920.

Shive, J. W. ('I5). Physiol. Res. I: 357-378. I9I 5.

- ('20). Jour. Agr. Res. 18: 327-397. 1920.

and Jones, L. H. ('2I). Soil Sci. II: 93-100. I92 I

Stoklasa, J., et al. ('I 8 a). Biochem. Zeitschr. 88: 292-322. I9I8.

('1 8 b). Biochem. Zeitschr. 91: I37-232. I91 8.

Sturtevant, E. L. ('94). Bull. Torrey Bot. Club 21:319-343. I894.

Szücs, J. ('I2). Jahrb. Wiss. Bot. 52: 269-332. I9I2.

Tottingham, W. E. ('14). Physiol. Res. I: I33-245. I9I4.

and Hart, E. B. ('I5). Jour. Agr. Res. 5: 233-250. I9I5.

True, R. H. ('21). Jour. Amer. Soc. Agron. I3: 9I-I07. I92I.

\section{EXPLANATION OF PLATE IV}

FIG. A. Relative growth in solutions "A" and " $\mathrm{H}$ " when $\mathrm{FePO}_{4}$ was supplied as a source of iron. Numbers I, 2, and 3 are in solution "A," with 3.5, I4, and $35 \mathrm{mg}$. FePO per 1., respectively. Number 4 is solution " $\mathrm{H}$ " with $7 \mathrm{mg}$. FePO 4 per 1.

FIG. $B$. Effect of $0.0004 N$ acids and their aluminum salts in solution "H."

FIG. $C$. Effect of $0.0004 N$ acids and their ferric salts upon root development in solution "H." 



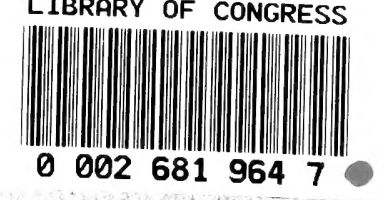

